\section{Akabane viral encephalitis in calves in South Korea}

\author{
J-K. LEE, J-H. KIM, B-K. PARK, H-S. YoO, \\ B-C. LEE, D-Y. KIM
}

AKABANE disease, caused by Akabane virus, an arthropodborne Bunyavirus, is known to be associated with abortion, stillbirth, premature births and congenital abnormalities in cattle, goats and sheep (Inaba and others 1975). Sporadic outbreaks have been recorded in several countries, including Japan and Taiwan (Inaba and others 1975, Charles 1994). In the Republic of Korea, the first outbreak of Akabane disease was reported in 1980 (Bak and others 1980).

The pathogenesis of Akabane virus infection has been demonstrated in both spontaneous and experimental cases (Kurogi and others 1977, Konno and others 1982, Kirkland and others 1988). Pregnant cows infected with Akabane virus develop transient viraemia without any apparent clinical signs; the virus then spreads haematogenously to the fetus. Following infection with Akabane virus at between approximately 76 and 249 days' gestation, fetuses develop various congenital abnormalities (Kirkland and others 1988). The manifestations of arthrogryposis, hydranencephaly or porencephaly, muscular atrophy and non-suppurative encephalomyelitis are dependent on the age of the fetus at the time of infection.

Although encephalomyelitis induced by Akabane virus is rare in cattle after birth, a few reports of this condition caused by a highly virulent Akabane virus strain, the Iriki strain, have been reported in Japan and Taiwan (Miyazato and others 1989, Liao and others 1997). These results suggested that Akabane virus may have the potential to cause non-suppurative inflammation in the brain and spinal cord of cattle through horizontal rather than vertical transmission (Miyazato and others 1989, Liao and others 1997).

This short communication describes lymphohistiocytic encephalomyelitis associated with Akabane virus in calves with neurological disorders in South Korea.

Between September 2000 and April 2001, eight calves, ranging in age from three days to four months, showing neurological signs such as hypersensitivity, tremor, locomotor ataxia and lameness, were submitted from dairy farms located in Kang-won and Kyoung-gi provinces to the College of Veterinary Medicine, Seoul National University, Republic of Korea, shortly after death for diagnosis.

After a complete postmortem examination, samples of brain, spinal cord, heart, liver, spleen, lung, skeletal muscles, thymus, stomach, kidney and small and large intestines were collected from each calf and fixed in 10 per cent neutral phosphate-buffered formalin. The tissues were then routinely processed, embedded in paraffin and stained with haematoxylin and eosin for light microscopy. Brain sections were taken from the cerebral cortex, midbrain, cerebellum, pons and medulla oblongata. Two sections were taken from each cervical, thoracic and lumbar spinal cord. The microscopic lesion severity was graded as mild, moderate or severe, based on the extent of the non-suppurative encephalomyelitis such as perivascular cuffing, gliosis, neuronophagia and neuronal loss.

Serum neutralisation (SN) tests for Akabane (OBE-1 strain) and Aino (JaNAr28 strain) viruses were performed as described by Uchida and others (2000). Sera were incubated at $56^{\circ} \mathrm{C}$ for 30 minutes to inactivate the complement, and diluted two- to 256-fold. The neutralisation antibody titres represent the high-

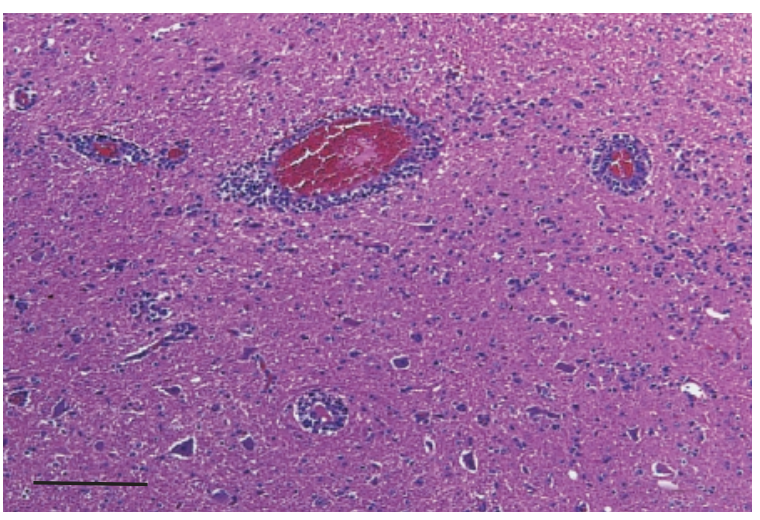

FIG 1: Perivascular cuffing by mononuclear cells and multifocal gliosis in the medulla oblongata of a newborn calf. Haematoxylin and eosin. Bar $=80 \mu \mathrm{m}$

est dilution rate of examined sera that inhibited a cytopathic effect of the cultured cells (Uchida and others 2000). The $\mathrm{SN}$ tests for bovine ephemeral fever, Ibaraki disease, bovine viral diarrhoea (BVD), Chuzan disease and Japanese B encephalitis were performed using standard methods (Lyoo and others 1997). Indirect fluorescent antibody tests for Neospora caninum and Chlamydia psittaci, an ELISA for Aujeszky's disease, were also performed using standard methods (Lyoo and others 1997, Kim and others 2000).

At postmortem examination, hypersalivation, torticollis and/or abnormal joints of the forelimb were noted in all eight calves, whereas there was no evidence of congenital brain and spinal cord abnormalities and arthrogryposis.

Histologically, lesions were limited to the brain and spinal cord. Moderate to severe lymphohistiocytic encephalomyelitis characterised by perivascular infiltration of mixed lymphocytes and histiocytes with fewer plasma cells, multifocal gliosis, neuronal degeneration, and occasional neuronophagia was the main change observed in the brains (Fig 1). Furthermore, mild perivascular lymphohistiocytic cuffing was randomly distributed in the submeningeal areas. Lymphohistiocytic perivascular cuffing, moderate gliosis and neuronal necrosis and loss were also observed in the spinal cord, mostly in the ventral horn grey matter (Fig 2). In one case, muscular atrophy of the limb muscle, with a mild inflammatory reaction, was observed (Table 1).

Results of the SN test for Akabane virus showed that five calves had antibody titres ranging from 1:16 to 1:256 (Table 1); the other three calves had no significant antibody titres (1:2). The antibody titres for Aino virus were 1:2 in all eight calves. All of the tested calves showed no significant antibody titres against Ibaraki disease, Chuzan disease, bovine ephemeral fever, Japanese B encephalitis and BVD. Antibody titres

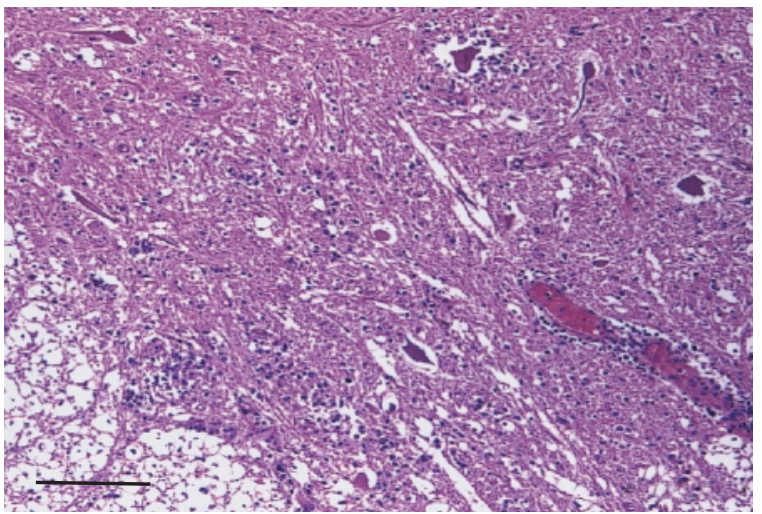

FIG 2: Gliosis and perivascular cuffing in the ventral horn of grey matter in the spinal cord of a newborn calf. Haematoxylin and eosin. Bar $=80 \mu \mathrm{m}$
Veterinary Record (2007) $161,236-238$

J-K. Lee, DVM, MSc, B-K. Park, DVM, PhD,

H-S. Yoo, DVM, PhD,

B-C. Lee, DVM, PhD,

D-Y. Kim, DVM, PhD, College of Veterinary Medicine and School of Agricultural Biotechnology, Seoul National University, Seoul 151-741, Republic of Korea

J-H. Kim, DVM, PhD, Department of Veterinary Medicine, Cheju National University, Jeju 690-756, Republic of Korea

Correspondence to Dr D-Y. Kim 


\begin{tabular}{|c|c|c|c|c|c|c|}
\hline \multirow[b]{2}{*}{ Calf } & \multirow[b]{2}{*}{ Age } & \multirow[b]{2}{*}{ Encephalomyelitis } & \multirow{2}{*}{$\begin{array}{l}\text { Muscle } \\
\text { atrophy }\end{array}$} & \multirow[b]{2}{*}{ Hydranencephaly } & \multicolumn{2}{|c|}{$\begin{array}{l}\text { Serum neutralising } \\
\text { antibody titres }\end{array}$} \\
\hline & & & & & Akabane virus & Aino virus \\
\hline 1 & 4 months & ++ & - & - & $1: 256$ & $1: 2$ \\
\hline 2 & 5 days & ++ & - & - & $1: 2$ & $1: 2$ \\
\hline 3 & 3 days & ++ & - & - & $1: 2$ & $1: 2$ \\
\hline 4 & 8 days & ++ & - & - & $1: 256$ & $1: 2$ \\
\hline 5 & 15 days & ++ & - & - & $1: 32$ & $1: 2$ \\
\hline 6 & 9 days & ++ & - & - & $1: 16$ & $1: 2$ \\
\hline 7 & 5 days & +++ & - & - & $1: 16$ & $1: 2$ \\
\hline 8 & 17 days & +++ & + & - & $1: 2$ & $1: 2$ \\
\hline
\end{tabular}

against $N$ caninum, $C$ psittaci and Aujeszky's disease virus were also negative.

The results of gross pathology, histopathology and serology indicated that the lymphohistiocytic encephalomyelitis in the eight calves was caused by Akabane virus infection (Table 1). The patterns of lesion were similar to those reported previously in Japan in calves infected with Akabane virus (Uchida and others 2000). Except for calf 1, the high levels of antibody titres in calves 4, 5, 6 and 7 were assumed to be of maternal origin. Other possible causes of encephalitis in calves were eliminated using appropriate antibody detection methods. From the history taken, it was found that the dairy farms that had submitted the cases did not vaccinate their stock against Akabane virus. Although seroprevalence of antibodies to Akabane virus differs every year, an increased incidence of abortion associated with Akabane virus usually occurs every five years. According to statistics from the Korean National Veterinary Research and Quarantine Service, antibodies to Akabane virus were found in 62.2 per cent and 55.6 per cent of dairy cows in 1995 and 2000, respectively (Lee and others 2000).

Akabane virus infection of a fetus during the early and middle gestation periods results in hydranencephaly/porencephaly and arthrogryposis, whereas during late gestation, degenerative encephalopathy is observed (Konno and others 1982, Kirkland and others 1988). In addition, as observed in the present study, non-suppurative encephalomyelitis may also occur with infection in late gestation without arthrogryposis and hydranencephaly syndrome.

Miyazato and others (1989) inoculated two calves intracerebrally with the virulent Iriki strain of the Akabane virus and, within two days of the inoculation, detected transient viraemia. Severe nervous signs were also observed between nine and 11 days after the inoculation. Although the virus used in that experiment had been isolated from experimentally infected calves, neutralising antibody titres were not detected in either of the experimental calves, in part indicating that serological analysis is of limited significance at this stage of Akabane disease (Miyazato and others 1989). Although the neutralising titres were not significantly increased in three of the calves in the present study, the calves showed severe diffuse non-suppurative encephalomyelitis, gliosis, perivascular cuffing and muscle atrophy, indicating that they had probably been infected with Akabane virus in the last month of gestation.

The four-month-old calf (calf 1) in the present study did not show any clinical signs during the first two months after birth, but thereafter gradually developed progressive neurological signs. Its histopathological changes and lesion distri- bution were essentially the same as those of the other calves examined in the study. Because a high neutralising antibody titre was detected in the calf, the authors considered that postnatally acquired Akabane virus infection was the cause of the encephalomyelitis. In Japan, an outbreak of Akabane disease has been reported in one- to 27-day-old calves and a five-month-old bull calf (Uchida and others 2000). Cases involving two- to seven-year-old adult cows have also been reported in South Korea (Lee and others 2002).

In addition to abortion, stillbirth, premature birth and congenital abnormalities generally caused by Akabane virus in calves, several studies, including the present study, have shown that Akabane virus can also cause non-suppurative inflammation in the brain and spinal cord of cattle after the neonatal period or even up to adult ages. Therefore, to reduce economic losses due to the Akabane virus, a well-controlled programme of vaccination, as well as in-depth characterisation of all newly isolated viruses, is highly recommended in endemic countries.

\section{ACKNOWLEDGEMENTS}

This work was supported by the Brain Korea 21 Project and the Ministry of Agriculture and Forestry (399002-3), Republic of Korea.

\section{References}

BAK, U. B., LIM, C. H., CHEONG, C. K., HWANG, W. S. \& CHO, M. R. (1980) Outbreaks of Akabane disease of cattle in Korea. Korean Journal of Veterinary Research 20, 65-78

CHARLES, J. A. (1994) Akabane virus. Veterinary Clinics of North America: Food Animal Practice 10, 525-546

INABA, Y., KUROGI, H. \& OMORI, T. (1975) Akabane disease: epizootic abortion, premature birth, stillbirth and congenital arthrogryposis-hydranencephaly in cattle, sheep and goats caused by Akabane virus. Australian Veterinary Journal 51, 584-585

KIM, J. H., SOHN, H. J., HWANG, W. S., HWANG, E. K., JEAN, Y. H., YAMANE, I. \& KIM, D. Y. (2000) In vitro isolation and characterization of bovine Neospora caninum in Korea. Veterinary Parasitology 90, 147-154

KIRKLAND, P. D., BARRY, R. D., HARPER, P. A. \& ZELSKI, R. Z. (1988) The development of Akabane virus-induced congenital abnormalities in cattle. Veterinary Record 122, 582-586

KONNO, S., MORIWAKI, M. \& NAKAGAWA, M. (1982) Akabane disease in cattle: congenital abnormalities caused by viral infection. Spontaneous disease. Veterinary Pathology 19, 246-266

KUROGI, H., INABA, Y., TAKAHASHI, E., SATO, K. \& SATODA, K. (1977) Congenital abnormalities in newborn calves after inoculation of pregnant cows with Akabane virus. Infection and Immunity 17, 338-343

LEE, J. K., PARK, J. S., CHOI, J. H., PARK, B. K., LEE, B. C., HWANG, W. S. KIM, J. H., JEAN, Y. H., HARITANI, M., YOO, H. S. \& KIM, D. Y. (2002) Encephalomyelitis associated with Akabane virus infection in adult cows. Veterinary Pathology 39, 269-273

LEE, O. S., CHO, J. J. \& YOON, S. R. (2000) Annual Research Reports of the National Veterinary Research and Quarantine Service. Anyang, National Veterinary Research and Quarantine Service. pp 441-449

LIAO, Y. K., LU, Y. S., GOTO, Y. \& INABA, Y. (1997) The isolation of Akabane virus (Iriki strain) from calves in Taiwan. Journal of Basic Microbiology 36, 33-39

LYOO, Y. S., PARK, C. K. \& CHANG, C. H. (1997) Bovine viral diseases. In Diagnostic Manual for Animal Diseases. 1st edn. Seoul, Leegong World Press. pp 143-177

MIYAZATO, S., MIURA, Y., HASE, M., KUBO, M., GOTO, Y. \& KONO, Y (1989) Encephalitis of cattle caused by Iriki isolate, a new strain belonging to Akabane virus. Japanese Journal of Veterinary Science 51, 128-136

UCHIDA, K., MURAKAMI, T., SUEYOSHI, M., TSUDA, T., INAI, K., ACORDA, J. A., YAMAGUCHI, R. \& TATEYAMA, S. (2000) Detection of Akabane viral antigens in spontaneous lymphohistiocytic encephalomyelitis in cattle. Journal of Veterinary Diagnostic Investigation 12, 518-524 